January 2005

\title{
Turfgrass Reflectance Measurements, Chlorophyll, and Soil Nitrate Desorbed from Anion Exchange Membranes
}

Salvatore S. Mangiafico

Karl Guillard

University of Connecticut Department of Plant Science, karl.guillard@uconn.edu

Follow this and additional works at: https://opencommons.uconn.edu/plsc_articles

\section{Recommended Citation}

Mangiafico, Salvatore S. and Guillard, Karl, "Turfgrass Reflectance Measurements, Chlorophyll, and Soil Nitrate Desorbed from Anion Exchange Membranes" (2005). Plant Science Articles. 10.

https://opencommons.uconn.edu/plsc_articles/10 


\title{
Turfgrass Reflectance Measurements, Chlorophyll, and Soil Nitrate Desorbed from Anion Exchange Membranes
}

\author{
Salvatore S. Mangiafico and Karl Guillard*
}

\begin{abstract}
There is not extensive research on the potential of anion exchange membranes (AEMs) for determining available $N$ in soils of turfgrass systems, nor on the use of reflectance meters for quantifying turfgrass color. The two objectives of this study were to determine relationships between (i) turfgrass color measurements and soil nitrate $\left(\mathrm{NO}_{3}-\mathrm{N}\right)$ desorbed from AEMs and (ii) reflectance meter measurements and turfgrass chlorophyll concentration. A field experiment was conducted on a $90 \%$ Kentucky bluegrass (Poa pratensis L.) stand across 2 yr. Anion exchange membranes were inserted into the soil and exchanged weekly. Desorbed $\mathrm{NO}_{3}-\mathrm{N}$ from the AEMs was quantified. Turfgrass color and chlorophyll measurements were taken monthly. Reflectance meter measurements were significantly related to chlorophyll concentration. Linear response plateau models suggested critical levels of AEM soil $\mathrm{NO}_{3}-\mathrm{N}$, above which turfgrass color did not improve, from 0.31 to $0.43 \mu \mathrm{g} \mathrm{cm}^{-2} \mathrm{~d}^{-1}$. These models suggest that critical levels of soil $\mathrm{NO}_{3}-\mathrm{N}$ could be determined that maximize turfgrass quality without excessive $\mathbf{N}$ application. These findings suggest both AEMs and hand-held reflectance meters could be useful tools for $\mathbf{N}$ management in turfgrass.
\end{abstract}

$T$ HERE IS CONCERN about $\mathrm{NO}_{3}-\mathrm{N}$ losses from managed turf areas because of negative environmental and human heath effects of $\mathrm{NO}_{3}-\mathrm{N}$ in surface and ground waters. Turf areas are often fertilized according to predetermined schedules, or fertilization is guided by turf quality. It would be desirable, however, to manage $\mathrm{N}$ fertilization in response to measured soil N. Managing N fertilization to optimize turf quality without applying excess $\mathrm{N}$ may reduce $\mathrm{N}$ losses from managed turfgrass areas. Because labile forms of $\mathrm{N}$ may be converted into $\mathrm{NO}_{3}-\mathrm{N}$ in well-aerated soils, and $\mathrm{NO}_{3}-\mathrm{N}$ is the form of $\mathrm{N}$ preferred by turfgrasses for assimilation, soil $\mathrm{NO}_{3}-\mathrm{N}$ concentrations may serve as a guide for $\mathrm{N}$ applications.

One method of measuring available soil $\mathrm{NO}_{3}-\mathrm{N}$ uses AEMs. Anion exchange membranes are nearly twodimensional strips of vinyl with anion exchange sites. Because of their two-dimensional nature and small size, they may be used for in situ soil $\mathrm{NO}_{3}-\mathrm{N}$ measurements with minimal disturbance to soil and plants. They are relatively easy to handle and process and can be used to monitor plant-available $\mathrm{NO}_{3}-\mathrm{N}$ in soil over time.

Studies have shown that AEM desorbed $\mathrm{NO}_{3}-\mathrm{N}$ is related to soil $\mathrm{NO}_{3}-\mathrm{N}$ obtained with traditional soil extractions. These studies include correlations to extraction with $0.001 M \mathrm{CaCl}_{2}$ (Qian et al., 1992), $2 \mathrm{M} \mathrm{KCl}$ (Pare et al., 1995; Subler et al., 1995), and water (Ziadi et al.,

Dep. of Plant Science, Unit 4067, University of Connecticut, 1376 Storrs Road, Storrs, CT 06269-4067. Received 17 Dec. 2003. *Corresponding author (karl.guillard@uconn.edu).

Published in Crop Sci. 45:259-265 (2005).

(c) Crop Science Society of America

677 S. Segoe Rd., Madison, WI 53711 USA
1999) in a variety of locations and soil types. The AEM technique, however, may be more sensitive than traditional extractions to treatment differences at low soil $\mathrm{NO}_{3}-\mathrm{N}$ concentrations (Pare et al., 1995; Wander et al., 1995). Studies have reported AEM desorbed $\mathrm{NO}_{3}-\mathrm{N}$ to be related to $\mathrm{N}$ uptake in forage grasses (Ziadi et al., 1999) and in canola (Brassica napus L.) (Qian et al., 1992). In a field experiment with a perennial grassland, Collins and Allinson (1999) modeled forage grass yields to AEM desorbed soil $\mathrm{NO}_{3}-\mathrm{N}$ using linear response plateau and quadratic response plateau relationships. Critical levels of AEM desorbed $\mathrm{NO}_{3}-\mathrm{N}$, above which there was no further increase in yield, were typically between 0.5 and $4 \mu \mathrm{g} \mathrm{cm}^{-2} \mathrm{~d}^{-1}$.

Studies reporting results for the use of AEMs to assess available $\mathrm{NO}_{3}-\mathrm{N}$ in turfgrass systems are limited. Kopp and Guillard (2002) in a field experiment on home lawn turf of mixed species in Connecticut, reported significant quadratic response plateau models of clipping matter dry yields to AEM desorbed soil $\mathrm{NO}_{3}-\mathrm{N}$ by harvest period. Critical values of soil $\mathrm{NO}_{3}-\mathrm{N}$, above which there were no further increases in yield, were typically between 0.4 and $10 \mu \mathrm{g} \mathrm{cm}^{-2} \mathrm{~d}^{-1}$. They also reported similar results for quadratic response plateau models of visual turf quality. Critical values typically were between 0.3 and $19 \mu \mathrm{g}$ $\mathrm{cm}^{-2} \mathrm{~d}^{-1}$. Additionally, Desjardins et al. (1998) reported initial results for a relationship between tissue- $\mathrm{N}$ in turfgrass and AEM desorbed soil N.

Turfgrass quality is often measured on a subjective visual scale. While visual ratings may be highly reliable in evaluating treatment differences, they are not comparable across studies or evaluators. If $\mathrm{N}$ management is to be based on quality measurements, objective quality measurements must be employed. Objective quality measurements employed in turfgrass evaluations commonly include clipping yield and leaf chlorophyll concentration. High clipping yield itself may not be a desirable characteristic, but may be considered to be an overall measure of plant vitality. Chlorophyll concentration similarly may be considered to be a measure of plant vitality, or may be viewed as an indirect measure of turf color (Pocklington et al., 1974). Chlorophyll concentration and yield measurements, however, suffer from the disadvantages of being time and labor intensive. Furthermore, direct chlorophyll concentration measurements require access to a spectrophotometer, and are therefore not practical for all turfgrass managers.

Tristimulus chroma meters and chlorophyll reflectance meters are two tools that may be used to assess turfgrass color quickly and reliably and report quantitative, objective results. Chroma meters measure whole color

Abbreviations: AEM, anion exchange membrane; CIE, Commission Internationale de l'Eclairage. 
in a number of coordinate systems, including the Commission Internationale de l'Eclairage (CIE) 1976 L*, a*, b* system (Hunter, 1975). These color parameters may be converted to the more intuitive hue, chroma, and lightness measurements (McGuire, 1992). Because more desirable turf tends to have greener hue and lower lightness, chroma meter measurements may be considered a direct measure of turf leaf color. Additionally, these measurements may be considered indirect measurements of physiological parameters, including chlorophyll content in apple (Malus domestica Borkh), grape (Vitis labrusca L.), and peach (Prunus persica L.) (Singha and Townsend, 1989); chlorophyll concentration in vegetable skins (Lancaster et al., 1997); chlorophyll concentration in watercress (Nasturtium officinale R. Br.) (Meir et al., 1992); and tissue $\mathrm{N}$ concentration in maize (Zea mays L.) leaves (Graeff et al., 2001).

Few studies have reported results of using chroma meters on turf. Landschoot and Mancino (2000) reported results of chroma meter measurements in situ on bentgrass cultivars (Agrostis stolonifera L., A. capillaris L.). They reported that the chroma meter was sensitive to cultivar differences. Additionally, they reported a positive correlation of CIE hue and subjective color assessment across evaluators and cultivars, and a negative correlation of CIE chroma and subjective color assessment.

The Spectrum CM 1000 (Spectrum Technologies, Inc. Plainfield, IL) is a hand-held chlorophyll reflectance meter. It works on a similar principle to the SPAD meter (Soil-Plant Analysis Development, Konica Minolta Holding, Inc., Tokyo, Japan); however, while the SPAD meter requires a leaf width of at least $2 \mathrm{~mm}$, the Spectrum meter is applicable for use on the canopy of fine-leafed turf stands. The ability to make canopy measurements allows for a measurement that assesses a wider area and integrates many leaf surfaces. Reflectance meter measurements on individual leaves, using algorithms similar to that employed by the Spectrum meter, have been correlated to chlorophyll concentration, visual quality, and tissue $\mathrm{N}$ in St. Augustinegrass [Stenotaphrum secondatum (Walt.) Kuntze] (Rodriguez and Miller, 2000), and to tissue $\mathrm{N}$ in cotton (Gossypium hirsutum L.) (Tarpley et al., 2000). Measuring canopy reflectance, Trenholm et al. (1999) found linear correlations between visual quality and visual density and an index of reflected light in seashore paspalum (Paspalum vaginatum Swartz) and bermudagrass (Cynodon dactylon L. $\times$ C. transvaalensis Burtt-Davy).

One purpose of this study was to explore the relationship between soil $\mathrm{N}$ measured with AEMs and turfgrass color to estimate optimum soil $\mathrm{NO}_{3}-\mathrm{N}$ concentrations for turfgrass color. This objective is similar to that proposed by Kopp and Guillard (2002), except the present study was conducted with a different species composition, soil type, and includes the use reflectance meters to quantify turf color. Another purpose was to explore the relationship among turfgrass reflectance measurements and chlorophyll concentration to assess the applicability of reflectance meters in optimizing turf quality.

\section{MATERIALS AND METHODS}

\section{Experimental Design and Management}

A field experiment was conducted at the University of Connecticut in Storrs, CT, USA, during two consecutive growing seasons (2001 and 2002). Field plots, measuring 1.4 by $2.4 \mathrm{~m}$ each were arranged in a completely random design. In the summer of 2000, existing vegetation on the site was killed with glyphosate [ $N$-(phosphonomethyl)glycine] and tilled into the soil. The entire site was topped with $20 \mathrm{~cm}$ of commercial topsoil to mimic the soil profile of a newly constructed home lawn. The topsoil was graded by hand and rolled, and commercially grown sod was applied. The sub soil had a texture of loamy sand, a $\mathrm{pH}_{(1: 1)}$ of $5.7,14 \mathrm{~g} \mathrm{~kg}^{-1}$ organic matter by dry combustion (Ball, 1964), and $8.0 \mathrm{mg} \mathrm{kg}^{-1} \mathrm{NO}_{3}-\mathrm{N}$ by $2 \mathrm{M} \mathrm{KCl}$ extraction (Mulvaney, 1996). The topsoil had a texture of loamy sand, a $\mathrm{pH}_{(1: 1)}$ of $5.9,19 \mathrm{~g} \mathrm{~kg}^{-1}$ organic matter, and $9.4 \mathrm{mg} \mathrm{kg}^{-1}$ $\mathrm{NO}_{3}-\mathrm{N}$. The site was then sodded with a $90 \%$ Kentucky bluegrass and $10 \%$ creeping red fescue (Festuca rubra L.) mixture.

The site was maintained as a home lawn. Each plot received $49 \mathrm{~kg} \mathrm{~N} \mathrm{ha}^{-1}$ on each of two applications, one in early May and one in late June, of a 30-1.7-3.2 (N-P-K) commercial lawn fertilizer. This fertilizer had $9 \%$ of $\mathrm{N}$ as $\mathrm{NH}_{4}^{+}, 74 \%$ as urea, and $17 \%$ as water-insoluble N. Each plot also received $49 \mathrm{~kg}$ $\mathrm{N} \mathrm{ha}^{-1}$ of a 10-7-17 commercial lawn fertilizer on one of the following dates: 15 September, 15 October, 15 November, 15 December, or received no fall fertilizer. This fertilizer had $60 \%$ of $\mathrm{N}$ as $\mathrm{NH}_{4}^{+}$and $40 \%$ as urea. This fertilization plan resulted in each fall-fertilized plot receiving $147 \mathrm{~kg} \mathrm{~N}^{-1}$ $\mathrm{yr}^{-1}$ and each control plot receiving $98 \mathrm{~kg} \mathrm{~N} \mathrm{ha}^{-1} \mathrm{yr}^{-1}$. Plots that received no fall fertilizer received additional $\mathrm{P}$ as triple superphosphate and additional $\mathrm{K}$ as $\mathrm{KCl}$ the following spring so that all plots received the same amounts of $\mathrm{P}$ and $\mathrm{K}$. Plots were mowed weekly during the growing season to a height of $4.5 \mathrm{~cm}$ and clippings remained on the plots. Plots were irrigated at a rate of $2.5 \mathrm{~cm} \mathrm{wk}^{-1}$ from May to September in addition to receiving natural precipitation. Dolomitic limestone was applied as needed to maintain a $\mathrm{pH}_{(1: 1)}$ of 6.0 or higher. Any weeds were removed by hand and plots were sprayed in September 2002 with the broadleaf selective herbicide 2,4-D (2,4-dichlorophenoxyacetic acid).

\section{Anion Exchange Membranes}

Beginning in March 2001, plant-available $\mathrm{NO}_{3}-\mathrm{N}$ was measured in situ with AEM strips (Ionics, Inc., Watertown, MA). Each week, one AEM strip was inserted into each plot, and the strip from the preceding week was removed. This was done throughout the year, whenever the ground was not frozen and not covered with snow. Strips were inserted and collected from 26 March to 24 Dec. 2001, and from 25 Feb. to 25 Nov. 2002. A slit was made into the soil at an angle of approximately $15^{\circ}$ from vertical with a mason's trowel and an AEM strip was inserted so that the top of the AEM was at the soil surface. Foot pressure was used to close the slit and ensure proper soil contact with the AEM. A monofilament line and flagging tape was attached to each AEM to facilitate removal. A new slit was made in a different location in the plot each time a new AEM was inserted.

The methodology used to prepare and process AEMs followed that of Kopp and Guillard (2002) and Collins and Allinson (1999). A large sheet of type-204 vinyl copolymer AEM fabric was cut into strips measuring 7.6 by $2.5 \mathrm{~cm}$. Strips were prepared by shaking in $0.5 \mathrm{M} \mathrm{HCl}$ for $5 \mathrm{~min}$, rinsing in deionized water, saturating with $\mathrm{Cl}^{-}$ions by shaking for $2 \mathrm{~h}$ in $1 \mathrm{M}$ $\mathrm{NaCl}$, and rinsing again in deionized water. Strips were stored in deionized water until use. 
Upon removal from plots, the AEMs were rinsed lightly with deionized water and placed individually in 60-mL HDPE bottles containing $25 \mathrm{~mL}$ of $1 \mathrm{M} \mathrm{NaCl}$. These bottles were transported immediately to the lab and shaken for $1 \mathrm{~h}$ in their individual bottles to desorb $\mathrm{NO}_{3}-\mathrm{N}$ from the AEMs. The resultant extracts were filtered through soil analysis papers having a retention range of 8 to $12 \mu \mathrm{m}$ (Schleicher and Schuell, Keene, $\mathrm{NH}$ ). Extracts were fixed with $\mathrm{H}_{2} \mathrm{SO}_{4}$ and stored at $4^{\circ} \mathrm{C}$ for up to $28 \mathrm{~d}$. Extracts were analyzed for $\mathrm{NO}_{3}-\mathrm{N}$ on a Scientific Instruments continuous flow analyzer (WESTCO, Danbury, CT) using the Griess-Ilosvay method (Keeney and Nelson, 1982).

\section{Color and Yield Measurements}

Color measurements of leaf blades were taken from March to November in 2001 and 2002. For each measurement, leaf blades were clipped from a small section of a plot and laid flat into an optically dense stack. A color measurement was taken using a Minolta CR200b chroma meter (Konica Minolta Holding, Inc., Tokyo, Japan) in CIE L* $\mathrm{a}^{*} \mathrm{~b}^{*}$ coordinates at illuminant condition $\mathrm{C}$. The leaf blades were then randomly rearranged in the stack and another color measurement was taken. This was repeated for four measurements for each plot. Values of $\mathrm{L}^{*}, \mathrm{a}^{*}$, and $\mathrm{b}^{*}$ were averaged per plot and converted to hue, lightness, and chroma values (McGuire, 1992).
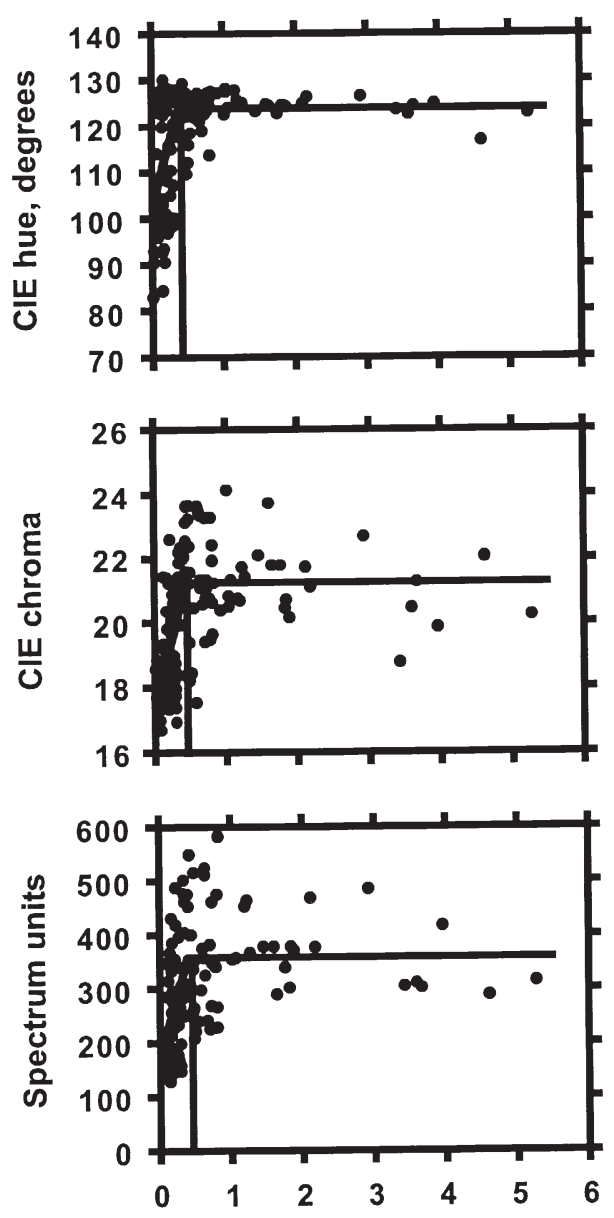

Chlorophyll concentration measurements in leaf tissue were taken from March to November in 2001 and 2002. For each measurement, leaf blades from a small section of a plot were clipped and collected. Chlorophyll extraction was performed on intact, fresh leaf tissue and $N, N$-dimethylformamide. Extracts were measured spectrophotometrically at 647 and $664.5 \mathrm{~nm}$ and chlorophyll concentration was calculated (Inskeep and Bloom, 1985).

Measurements with the Spectrum Field Scout CM 1000 chlorophyll meter were taken from September to December in 2001 and from March to November in 2002. Measurements were not made between March and August in 2001 only because the meter was not available at this time. Ten measurements were taken and averaged per plot. All measurements were taken in full sun between 1100 and $1300 \mathrm{~h}$ with the meter facing away from the sun. Measurements were taken holding the meter approximately $1.5 \mathrm{~m}$ from the turf canopy. This yielded a circular area of evaluation of approximately $180 \mathrm{~cm}^{2}$ per measurement. Clipping yield measurements were taken from April to October in 2001 and 2002. Leaf blades were clipped from a $0.05-\mathrm{m}^{2}$ area of a plot, dried at $71^{\circ} \mathrm{C}$, and weighed.

\section{Statistical Analyses}

Color and yield measurements for each treatment were plotted against the most recent in situ measurement of avail-
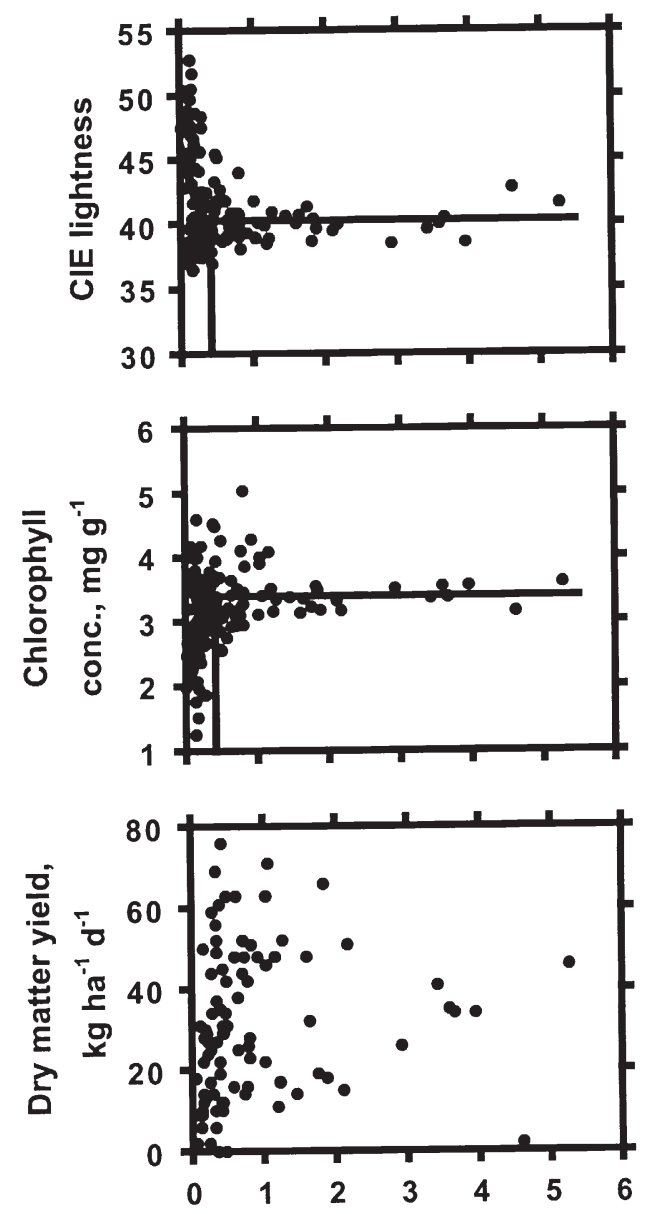

AEM desorbed $\mathrm{NO}_{3}-\mathrm{N}, \mu \mathrm{g} \mathrm{cm} \mathrm{cm}^{-1}$

Fig. 1. Linear response plateau plots of turfgrass color and yield measurements to $\mathrm{NO}_{3}-\mathrm{N}$ desorbed from AEMs across two growing seasons. Data are shown for AEMs used in situ at a depth of 0 to $7.6 \mathrm{~cm}$. Vertical lines to the $x$-axes in the plots indicate the critical level of AEMdesorbed $\mathrm{NO}_{3}-\mathrm{N}$, above which there is no change in turfgrass color to increasing AEM-desorbed $\mathrm{NO}_{3}-\mathrm{N}$. No linear plateau model is shown for dry matter yield because the model is not applicable. 
Table 1. Descriptors for linear plateau models of turfgrass color and yield versus AEM-desorbed soil $\mathrm{NO}_{3}-\mathrm{N}$. Number of observations $(N)$, probability value $(p)$, pseudo-coefficient of determination (pseudo- $\left.R^{2}\right) \dagger$, quality plateau values, critical level of AEM-desorbed soil $\mathrm{NO}_{3}-\mathrm{N}$ (Critical AEM), and approximate $95 \%$ confidence limits of the critical value of AEM-desorbed soil $\mathrm{NO}_{3}-\mathrm{N}\left(95 \% \mathrm{CL}^{2}\right.$ ). Data are shown for AEMs inserted at a depth of 0 to $7.6 \mathrm{~cm}$, with data combined across two growing seasons.

\begin{tabular}{|c|c|c|c|c|c|c|c|c|}
\hline Quality measure & $N$ & $p$ & pseudo- $R^{2}$ & Plateau & Plateau units & Critical AEM & Lower 95\% CL & Upper $95 \%$ CL \\
\hline & & & & & & & $-\mu \mathrm{g} \mathrm{cm} \mathbf{c m}^{-2} \mathrm{~d}^{-1}$ & \\
\hline CIE hue & 140 & $<0.0001$ & 0.314 & 124 & degrees & 0.368 & 0.276 & 0.460 \\
\hline CIE lightness & 140 & $<0.0001$ & 0.199 & 40.2 & (none) & 0.310 & 0.212 & 0.408 \\
\hline CIE chroma & 140 & $<0.0001$ & 0.438 & 21.2 & (none) & 0.427 & 0.340 & 0.513 \\
\hline Chlorophyll concentration & 140 & $\mathbf{0 . 0 0 0 3}$ & 0.101 & 3.38 & $\mathrm{mg} \mathrm{g}^{-1}$ & 0.383 & 0.176 & 0.590 \\
\hline Spectrum units & 115 & $<0.0001$ & 0.240 & 358 & (none) & 0.394 & 0.263 & 0.526 \\
\hline Dry matter yield & 90 & $\mathbf{N} / \mathbf{A} \div$ & N/A & N/A & N/A & N/A & N/A & N/A \\
\hline
\end{tabular}

$\dagger$ Equal to $\{1-[($ sum of squares for residuals $) /($ corrected total sum of squares $)]\}$.

$\uparrow$ Model not applicable. Model assumption of homoscedasticity violated.

able soil $\mathrm{NO}_{3}-\mathrm{N}$, and linear response plateau models were generated for data across two growing seasons. These linear plateau models fit a line of changing crop response with increasing soil $\mathrm{NO}_{3}-\mathrm{N}$ when soil $\mathrm{NO}_{3}-\mathrm{N}$ is below some critical value. Above this critical value, the models predict no change in crop response with increasing soil $\mathrm{NO}_{3}-\mathrm{N}$. The crop response at and above the critical level is called the plateau value (Cerrato and Blackmer, 1990).

Turfgrass color measurements were plotted against other color measurements of the same date and an appropriate linear or nonlinear model was generated for the pooled data of two growing seasons. Because the experiment was conducted as a replicated experiment, treatment averages were used for all models (Gomez and Gomez, 1984). Linear, linear response plateau, and nonlinear models were generated by the NLIN and REG procedures of the Statistical Analysis Software package (SAS Institute, 1999). All models were checked for homoscedasticity, normality of residuals, and independence of residuals (Tabachnick and Fidell, 2001). Although the experiment was conducted as a replicated experiment, treatment effects are not relevant to this study and are not reported.

\section{RESULTS AND DISCUSSION Turfgrass Quality and Desorbed $\mathrm{NO}_{3}-\mathrm{N}$ from AEMs}

Statistically significant $(p<0.01)$ linear response plateau models relating color measurements to AEM desorbed $\mathrm{NO}_{3}-\mathrm{N}$ were generated (Fig. 1). Linear plateau models were generated for each color measurement but not for clipping yield (for which the model was not applicable because of the data's violation of the model's assumption of homoscedasticity). Model parameters are presented in Table 1. Among color measurements, critical levels of AEM desorbed $\mathrm{NO}_{3}-\mathrm{N}$ ranged from 0.31 to $0.43 \mu \mathrm{g} \mathrm{cm}^{-2} \mathrm{~d}^{-1}$. The range of these critical levels overlap with the range of critical levels for visual quality ratings on mixed-species turfgrass plots presented by Kopp and Guillard (2002), although in general the critical values of the present study are lower. This difference might be attributable to the difference in species composition of the two studies. Kopp and Guillard (2002) used $35 \%$ Kentucky bluegrass, $35 \%$ creeping red fescue, and $30 \%$ perennial ryegrass (Lolium perenne L.). Pseudo- $R^{2}$ values for linear plateau models of the present study ranged from 0.10 to 0.44 (Table 1 ). Considering that these models compared frequent color measurements to soil $\mathrm{NO}_{3}-\mathrm{N}$ values across two growing seasons, and that these values were not averaged across time or adjusted for season or environmental conditions, these pseudo- $R^{2}$ values represent reasonable predictive power. The consistency of critical values among color measurements and the statistical significance of the models across two growing seasons suggest that AEMs show promise in estimating a threshold AEM soil $\mathrm{NO}_{3}-\mathrm{N}$ concentration which would achieve maximum color of a predominantly Kentucky bluegrass turf without excess $\mathrm{N}$ application.

The establishment of critical levels would allow turf managers to perform a soil $\mathrm{NO}_{3}-\mathrm{N}$ test employing the AEM technique, and then apply $\mathrm{N}$ fertilizer only if the desorbed $\mathrm{AEM} \mathrm{NO}_{3}-\mathrm{N}$ value were below that critical value or range of values. More studies, however, are needed to accurately estimate critical levels across a variety of soils, turf species, and management regimes, and to determine if the established critical values will be robust against these different conditions. From the few studies available, it is not clear if AEMs would be more useful as a soil test at one time during the growing season or used throughout the growing season as an end-of-the-year assessment of soil $\mathrm{NO}_{3}-\mathrm{N}$. It is unknown also how AEM critical levels should be adjusted for seasonal or other environmental effects. These questions should be addressed with future research.

\section{Turfgrass Responses and Experimental Design}

It is important to note that by the design of this experiment $\mathrm{N}$ fertilization rates were similar among treatments, and there was not a wide range of soil $\mathrm{NO}_{3}-\mathrm{N}$ concentrations for many sampling dates during the growing season. Amounts of $\mathrm{N}$ fertilizer applied annually did not vary greatly among plots. Specifically, throughout the spring and summer, soil $\mathrm{NO}_{3}-\mathrm{N}$ concentrations were similar across all plots. Soil $\mathrm{NO}_{3}-\mathrm{N}$ concentrations tended to be highest during August and September (Fig. 2), probably from increased mineralization during higher soil temperatures. The highest color values, however, tended to occur in April and May, when conditions were ideal for cool-season turfgrass growth, but soil $\mathrm{NO}_{3}-\mathrm{N}$ concentrations were relatively low. These high color measurements are visible in Fig. 1 as data points above the plateau at soil $\mathrm{NO}_{3}-\mathrm{N}$ concentrations below critical levels. The largest contemporaneous differences in soil $\mathrm{NO}_{3}-\mathrm{N}$ occurred in September and October (Fig. 2), probably as a result of the different timing of fall fertilizer application. Because of the design of the experiment, these models do not necessarily predict the highest turf 


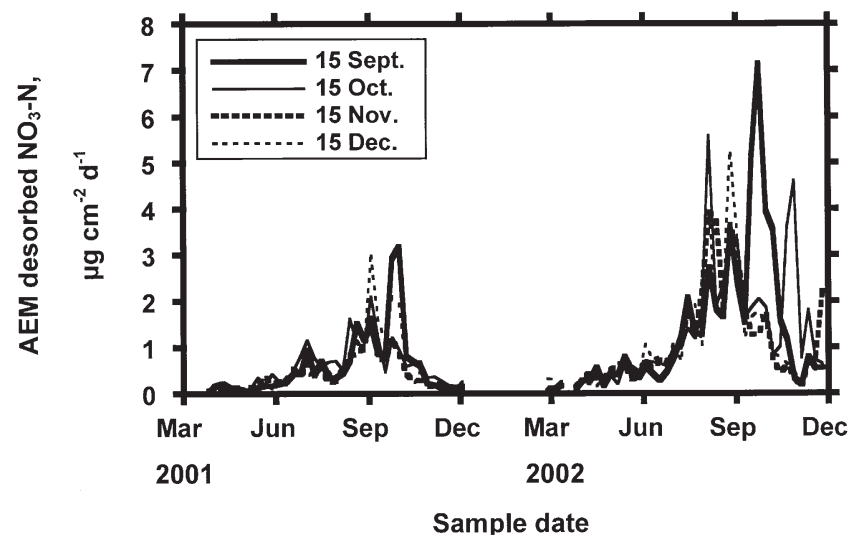

Fig. 2. Mean AEM desorbed soil $\mathrm{NO}_{3}-\mathrm{N}$ for fall-fertilized treatments versus sampling date. Data is presented for turfgrass across two growing seasons.

color values for any specific date. However, they do suggest that for most of the growing season, turf color would not be improved with soil $\mathrm{NO}_{3}-\mathrm{N}$ concentrations beyond the indicated critical levels.

\section{Relationships Among Turfgrass Quality Measurements}

Significant bivariate relationships were found between some pairs of turfgrass quality measurements (Fig. 3). Parameters for these relationships are shown in Table 2. Relationships that appeared to be either curvilinear or linear plateau models were initially modeled as twolinear-segment models (data not shown). Those measurements with models in which the slope of the second segment was not statistically different from zero were assumed to be linear plateau relationships. The others were assumed to be curvilinear. For curvilinear relationships, in the absence of any theoretical models governing quality measurements, a general power relationship $\left(y=a+b x^{c}\right)$ was employed as an empirical model (Table 2).

Measurements from both reflectance meters employed in this study - the Minolta chroma meter and the Spectrum chlorophyll meter-were significantly related to chlorophyll concentration measurements (Fig. 3, A, B, D; Table 2). Considering measurements from the chroma meter, CIE chroma was unrelated to chlorophyll concentration, while both CIE lightness and CIE hue were related to chlorophyll with linear plateau relationships. These relationships suggest that turf will not appear more green or more darkly colored at chlorophyll concentrations above some critical value, about $3.4 \mathrm{mg} \mathrm{g}^{-1}$ in this study (Table 2).

Measurements from the Spectrum chlorophyll meter, however, showed no plateau with increasing chlorophyll concentration, or vice-versa (Fig. 3, D; Table 2). However, by chance, no measurements with the Spectrum meter were made on plots when chlorophyll concentrations were highest. Additionally, a significant linear relationship was found between measurements from the Spectrum meter and clipping yield measurements (Table 2). This relationship suggests that the Spectrum meter measurements indicate not only chlorophyll concentration in leaf tissue but also possibly the density of leaf blades in the sampled turf canopy. This suggestion is supported by Ma et al. (1996) who found canopy reflectance to be related to the product of chlorophyll content and leaf area in the canopy of corn plants and by Tren-


Fig. 3. Relationships among color measurements on turfgrass across two growing seasons. Linear response plateau models are shown for plots A and B. Power relationships are shown for plots D, E, and F. No model is shown for plot C because no significant model was found. 
Table 2. Significant relationships among turfgrass color and yield measurements. Number of observations $(N)$, probability value $(p)$, coefficient of determination $\left(r^{2}\right)$, pseudo-coefficient of determination (pseudo- $\left.R^{2}\right) \dagger, x$-axis critical value $(C L)$, and model parameters $(a, b, c)$. Units are CIE hue (degrees), chlorophyll concentration $\left(\mathrm{mg} \mathrm{g}^{-1}\right)$, and dry matter clipping yield ( $\left.\mathrm{kg} \mathrm{ha}^{-1} \mathrm{~d}^{-1}\right)$. All other measurements without units.

\begin{tabular}{|c|c|c|c|c|c|c|c|}
\hline$x$-axis quality measure & $y$-axis quality measure & $N$ & $p$ & pseudo- $R^{2}$ & $a$ & $b$ & $c$ \\
\hline \multicolumn{8}{|c|}{ General power relationship $\left(y=a+b x^{c}\right)$} \\
\hline Spectrum units & CIE hue & 110 & $<0.0001$ & 0.932 & 135 & -66400 & -1.48 \\
\hline Spectrum units & CIE lightness & 110 & $<0.0001$ & 0.845 & 36.8 & 42800 & $-\mathbf{1 . 6 4}$ \\
\hline Spectrum units & chlorophyll concentration & 110 & $<0.0001$ & 0.785 & 4.90 & -46.2 & -0.58 \\
\hline \multirow[t]{2}{*}{$x$-axis quality measure } & $y$-axis quality measure & $\boldsymbol{N}$ & $p$ & pseudo- $R^{2}$ & $C L$ & $a$ & $b$ \\
\hline & - Linear plateau relations & if $x<$ & then $y=a$ & $x$; else $y=c$ & $(C L))$ & & - \\
\hline \multirow{2}{*}{$\begin{array}{l}\text { Chlorophyll concentration } \\
\text { Chlorophyll concentration }\end{array}$} & CIE hue & 140 & $<0.0001$ & 0.764 & 3.38 & 46.8 & 23.4 \\
\hline & CIE lightness & 140 & $<\mathbf{0 . 0 0 0 1}$ & 0.703 & 3.42 & 62.9 & -6.99 \\
\hline \multirow[t]{2}{*}{$x$-axis quality measure } & $y$-axis quality measure & $N$ & $p$ & \multicolumn{2}{|c|}{$r^{2}$} & $a$ & $b$ \\
\hline & 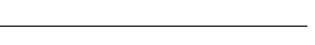 & Ir reg & n $(y=a+$ & . & 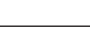 & 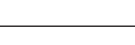 & - \\
\hline \multirow{2}{*}{$\begin{array}{l}\text { Spectrum units } \\
\text { CIE hue }\end{array}$} & dry matter yield & 65 & 0.0005 & \multirow{2}{*}{\multicolumn{2}{|c|}{$\begin{array}{l}0.176 \\
0.879\end{array}$}} & -7.03 & 0.0779 \\
\hline & CIE lightness & 140 & $<0.0001$ & & & 77.1 & -0.301 \\
\hline
\end{tabular}

$\dagger$ Equal to $\{1-[($ sum of squares for residuals)/(corrected total sum of squares) $]\}$.

holm et al. (1999) who found a linear correlation between canopy reflectance in some grasses and visual density. This relationship may be considered an advantage of the use of the Spectrum meter in turfgrass applications.

Measurements from the Spectrum meter were significantly related to CIE hue and CIE lightness from the chroma meter (Fig. 3, E, F; Table 2). These data suggest that the measurements from the Spectrum meter may be considered an index of leaf hue and darkness, as well as chlorophyll concentration.

Both reflectance meters employed in this study - the Minolta chroma meter and the Spectrum chlorophyll meter-provided reliable indications of chlorophyll concentration in turfgrass leaves throughout growing seasons and across years. Both meters were fairly quick and easy to use. The Minolta chroma meter was somewhat more time consuming to use because it required clipping leaf blades, arranging them into a stack, taking a measurement, and then repeating the process. Landschoot and Mancino (2000), however, were able to use this meter in situ on fine-textured, low-cut bentgrass. Additionally, the chroma meter sampled only a very small collection of leaf blades at a time. The Spectrum meter, in contrast, was able to sample a larger area of turf canopy without disturbing the turf. The Spectrum meter does not have its own light source, but relies on incident light and adjusts its reported values to the level of incident light. In this study, seasonal changes in light did not appear to affect measurements adversely from the Spectrum meter. The data from this study suggest that hand-held reflectance meters could be used to guide $\mathrm{N}$ management. If plateau values for any reflectance meter measurement could be established, $\mathrm{N}$ would be applied only on those turf areas yielding significantly lower measurement values. Perhaps the best way to establish these plateau values would be, on a site-specific basis, to establish small areas under a range of fertility regimes, against which to compare other turf areas. Those areas with reflectance meter values significantly below that of the high fertility area would require additional fertilization. Future study, however, is needed to determine the viability of this approach as well as the applicability of reflectance meters across a variety of turf species and environmental conditions and management.

\section{REFERENCES}

Ball, D.F. 1964. Loss-on-ignition as an estimate of organic matter and organic carbon in non-calcareous soils. J. Soil Sci. 15:84-92.

Cerrato, M.E., and A.M. Blackmer. 1990. Comparison of models for describing corn yield response to nitrogen fertilizer. Agron. J. 82: $138-143$.

Collins, S.A., and D.W. Allinson. 1999. Use of anion exchange membranes to assess nitrogen needs of perennial grasslands. Commun. Soil Sci. Plant Anal. 30:2267-2282.

Desjardins, Y., M. Tardif, and R.R. Simard. 1998. Determination of nitrogen availability in turfgrass soils with exchange resins. p. 14 . In Agronomy Abstr. ASA, CSSA, and SSSA, Madison, WI.

Gomez, K.A., and A.A. Gomez. 1984. Statistical procedures for agricultural research, 2nd ed. John Wiley \& Sons, New York.

Graeff, S., S. Diedrich, and S. Schubert. 2001. Use of reflectance measurements for the early detection of N, P, Mg, and Fe deficiencies in Zea Mays L. J. Plant Nutr. Soil Sci. 164:445-450.

Hunter, R.S. 1975. The measurement of appearance. John Wiley \& Sons, New York.

Inskeep, W.P., and P.R. Bloom. 1985. Extinction coefficients of chlorophyll $a$ and $b$ in N,N-dimethylformamide and $80 \%$ acetone. Plant Physiol. 77:483-485.

Keeney, D.R., and D.W. Nelson. 1982. Nitrogen-inorganic forms. p. 643-698. In A.L. Page et al. (ed.) Methods of soil analysis, 2nd ed., Part 2, Chemical and microbiological properties. ASA and SSSA, Madison, WI.

Kopp, K.L., and K. Guillard. 2002. Relationship of turfgrass growth and quality to soil nitrate desorbed from anion exchange membranes. Crop Sci. 42:1232-1240.

Lancaster, J.E., C.E. Lister, P.F. Reay, and C.M. Triggs. 1997. Influence of pigment composition on skin color in a wide range of fruit and vegetables. J. Am. Soc. Hortic. Sci. 122:594-598.

Landschoot, P.J., and C.F. Mancino. 2000. A comparison of visual vs. instrumental measurement of color differences in bentgrass turf. HortScience 35:914-916.

Ma, B.L., M.J. Morrison, and L.M. Dwyer. 1996. Canopy light reflectance and field greenness to assess nitrogen fertilization and yield of maize. Agron. J. 88:915-920.

McGuire, R.G. 1992. Reporting of objective color measurements. HortScience 27:1254-1255.

Meir, S., S. Philosoph-Hadas, P. Gloter, and N. Aharoni. 1992. Nondestructive assessment of chlorophyll content in watercress leaves by a tristimulus reflectance colorimeter. Postharvest Biol. Technol. 2:117-124.

Mulvaney, R.L. 1996. Nitrogen-Inorganic forms. p. 1123-1184. In 
D.L. Sparks (ed.). Methods of soil analysis, Part 3, Chemical methods. ASA and SSSA, Madison, WI.

Pare, T., E.G. Gregorich, and B.H. Elliot. 1995. Comparison of soil nitrate extracted by potassium chloride and adsorbed on an anion exchange membrane in situ. Commun. Soil Sci. Plant Anal. 26: 883-898.

Pocklington, T.E., J.D. Butler, and T.K. Hodges. 1974. Color evaluation of Poa pratensis cultivars. J. Sports Turf Res. Inst. 66:134-140.

Qian, P., J.J. Schoenanu, and W.Z. Huang. 1992. Use of ion exchange membranes in routine soil testing. Commun. Soil Sci. Plant Anal. 23:1791-1804.

Rodriguez, I.R., and G.L. Miller. 2000. Using a chlorophyll meter to determine the chlorophyll concentration, nitrogen concentration, and visual quality of St. Augustinegrass. HortScience 35:751-754.

SAS Institute Inc. 1999. SAS Online Doc, version 8. Cary, NC.

Singha, S., and E.C. Townsend. 1989. Relationship between chromaticity values and chlorophyll concentration in apple, grape, and peach leaves. HortScience 24:1034.
Subler, S. J.M. Blair, and C.A. Edwards. 1995. Using anion-exchange membranes to measure soil nitrate availability and net nitrification. Soil Biol. Biochem. 27:911-917.

Tabachnick, B.G., and S.F. Fidell. 2001. Using multivariate statistics, 4th ed. Allyn and Bacon. Boston, MA.

Tarpley, L., K.R. Reddy, and G.F. Sassenrath-Cole. 2000. Reflectance indices with precision and accuracy in predicting cotton leaf nitrogen concentration. Crop Sci. 40:1814-1819.

Trenholm, L.E., R.N. Carrow, and R.R. Duncan. 1999. Relationship of multispectral radiometry data to qualitative data in turfgrass research. Crop Sci. 39:763-769.

Wander, M.M., D.V. McCracken, L.M. Shuman, J.W. Johnson, and J.E. Box. 1995. Anion-exchange membranes used to assess management impacts on soil nitrate. Commun. Soil Sci. Plant Anal. 26: $2383-2390$.

Ziadi, N., R.R. Simard, G. Allard, and J. Lafond. 1999. Field evaluation of anion exchange membranes as a $\mathrm{N}$ soil testing method for grasslands. Can. J. Soil Sci. 79:281-294. 